\title{
Academic Satisfaction of Latino Students: Differences and Predictors
}

\author{
David Edens (corresponding author) \\ Department of Human Nutrition and Food Science, Cal Poly Pomona \\ 3801 West Temple Ave, Pomona, California, 93801, United States \\ Tel: 1-909-869-5226 E-mail: dredens@cpp.edu
}

\begin{abstract}
Michael Allen
Records and Research, Fresno Pacific University 1717 South Chestnut Ave, Fresno, CA, 93702 United States

Tel: 1-559-453-7188 E-mail: Michael.Allen@fresno.edu

James Steen

Enrollment Management, Houston Baptist University 7502 Fondren Rd, Houston, Texas 77074, United States

Tel: 1-281-649-3752 E-mail: jsteen@hbu.edu
\end{abstract}

Received: June 2, 2016 Accepted: June 21, 2016 Published: August 19, 2016

doi:10.5296/jet.v3i2.9400 URL: http://dx.doi.org/10.5296/jet.v3i2.9400

\begin{abstract}
Using multiple hierarchical regression, this study investigated how Latino/a students' characteristics, academic major, campus climate, and faculty interactions explained the variance in students' levels of satisfaction with advising, course availability, and instruction at highly selective institutions. Latino/a students' satisfaction was found to significantly differ from some of their peers, but not from other White students. The regressions found that campus climate was the most significant predictor of all three areas, followed by student-faculty interactions.
\end{abstract}

Keywords: Academic Student Satisfaction, Latino Students, Latina Students, Multiple Regression 


\section{Introduction}

Latinos represent a significant portion of the population in United States. According to recent analyses, the US Census Bureau (2014) estimates that Latino/as represent $17 \%$ of the Unites States population. As the Latino/a population continues to grow, more Latino/as are accessing higher education. The Pew Research Center recently found that the number of Latino/as entering college is increasing, the high school dropout rate for Latino/as continues to decrease, and Latino/as represent one-quarter of all elementary and post-secondary students (Lopez \& Fry, 2013). More importantly, the percentage of Latino/as (49\%) attending college after high school now surpasses Whites (47\%) and African-Americans (45\%) (Lopez \& Fry). Therefore, it is increasing important that colleges and universities invest in serving this growing population by developing programs for and assessing the outcomes of Latino/a students.

Student satisfaction is one measurement used by many colleges and universities as part of a comprehensive overall assessment of student outcomes and university operations (Scanlon \& McComis, 2010). Astin (1993) stated, "Given the considerable investment of time and energy that most students make in attending college, their perceptions of the value of that experience should be given substantial weight" (p. 273). Institutions that measure student satisfaction can use that information to develop programs and services that meet students' needs, create a better institutional fit, and improve the satisfaction and outcomes of their students (Beltyukova \& Fox, 2002; Bryant, 2006).

Research indicates that students who are satisfied are more likely to persist to graduation (Kuh, Kinzie, Buckley, Bridges, \& Hayek, 2006; Kuh, Kinzie, Schuh, Whitt, \& Associates, 2005; Suhre, Jansen, \& Harskamp, 2007). Researchers have also shown that satisfied students tend to put more effort to their studies, have increased motivation, and express higher levels of institutional fit (Suhre et al., 2007). A high level of satisfaction during the first-year is especially predictive of students persisting to graduation (Borden, 1995). Additionally, student satisfaction levels affect the reputation of the school, which is directly and indirectly related to marketing, student recruitment, and alumni relations (Bryant, 2006; Hoyt \& Brown, 2003; Juillerat \& Schreiner, 2004).

There has been a significant amount of research on the Latino/a student population. Much of that research has focused on transition to college and racial climate on campus (Hernandez, 2000; Hurtado \& Carter, 1997; Hurtado, Milem, Clayton-Pedersn, \& Allen, 2002; Nora \& Cabrera, 1996). More recently, research has focused on student outcomes such as sense of belonging, analytical skills, and participation within a diverse community (Hurtado \& Ponjuan, 2005). Additionally, Nora (2004) examined how pre-college characteristics such a habitus and cultural capital affect campus fit and satisfaction. However, there has been little research that specifically studies Latino/a students' level of satisfaction with college. More precisely, there is often limited consideration of the college experiences that affect the levels of satisfaction for Latino/a students and how those experiences differ from those of their counterparts. 
This study attempts to address the existing gaps in literature by investigating the patterns and predictors of academic satisfaction among Latino/a student populations at research universities. Specifically, this research is guided by the following research questions:

1) What are the levels of academic satisfaction among Latino/a college students at highly selective institutions? How are the levels different from those of their peers of other racial groups?

2) What college experiences contribute to the levels of academic satisfaction among Latino/a college students at these institutions? How are the contributing college experiences different from those of their counterparts of other racial groups?

\section{Review of the Literature}

Throughout the literature, researchers have documented the importance of student satisfaction among college students. In fact, there is no other educational outcome that could arguably carry more weight than student satisfaction (Astin, 1993). Used to assess to student outcomes, student satisfaction is collected by many colleges and universities to gauge institutional effectiveness (Scanlon \& McComis, 2010). One definition of student satisfaction focuses on the gap between student expectations and educational experience as it is perceived from the student's perspective (Juillerat, 1995). Students who perceive that their experience in college has met their expectations tend to be satisfied.

In terms of outcomes, the literature suggests that there is a relationship between student satisfaction and persistence (Kuh et al., 2006; Kuh et al., 2005; Suhre et al., 2007). Students who are satisfied with their experiences on campus are more likely to stay in school. In another viewpoint, students who are successful academically are usually highly satisfied and engaged on campus (DeShields Jr., Kara, \& Kaynak, 2005; Schreiner \& Louis, 2006, 2008). Beyond the direct correlation to persistence and retention, student satisfaction is also directly related (Aitken, 1982; Bean \& Bradley, 1986; Pike, 1993) as well as indirectly related (Aitken, 1982) to achievement measures such as GPA, time spent studying, and graduation and motivation (Elkins, Braxton, \& James, 2000). Increased levels of student satisfaction have also been shown to correlate with perceived skills development in college (Bailey, 2009).

Overall student satisfaction includes metrics that evaluate "the total undergraduate experience, as well as with specific aspects of that experience, such as the quality of instruction, contacts with faculty and fellow students, curriculum, college administration, and facilities" (Astin, 1993, p. 273). Student satisfaction is critical for institutions to assess because it is one of the indicators of retention and student success. The interpersonal relationships that students have with their peers as well as faculty and staff support student success and student satisfaction (Kuh et al., 2005; Pascarella \& Terenzini, 2005; Tinto, 1993)

Astin (1993) identified five factors of student satisfaction related to the undergraduate experience: Relationships with faculty, curriculum and instruction, student life, individual support services, and facilities. However, "The single best predictor of student satisfaction with college is the degree to which they perceive the college environment to be supportive of 
their academic and social needs." (Kuh et al., 2006, p. 40). It also appears that student satisfaction is more dependent on the student's college experience as opposed to their entering characteristics (Astin, 1993).

Student satisfaction also indirectly relates to other factors on campus such as reputation (Williams, 2002), college rankings (Meredith, 2004), alumni relations (Bailey, 2009), and alumni giving (Bryant, 2006; Pate, 1993). Even more important in today's college environment, student satisfaction has an indirect impact on admissions marketing and decision-making (Dolinsky, 2010; Hoyt \& Brown, 2003; Meredith, 2004).

\subsection{College Experiences and Culture Contributing to Satisfaction}

Research has shown that various student experiences have an impact on student satisfaction. Some institutional practices linked to student satisfaction are academic advising, the experience of registering for classes, career counseling, financial settlement policies, and relationships with faculty members (Noel-Levitz, 2014). All of these necessary student services can enhance student satisfaction and success when performed well, but inversely these same institutional procedures can also contribute to low satisfaction from students whenever they are done poorly. According to Kotler and Fox (1995), students are generally satisfied with their education, but are often less satisfied with administrative student services. For example, "financial aid by itself may not be enough to ensure persistence, it nonetheless plays an important indirect role in educational attainment by shaping the nature of students' experiences once enrolled" (Pascarella \& Terenzini, 2005, p. 416). Students who struggle financially to settle their account because of unmet need or an ability to pay will understandably have lower student satisfaction.

"Student satisfaction", according to Elliott \& Healy, "is generally accepted as a short-term attitude resulting from an evaluation of a student's educational experience. Student satisfaction results when actual performance meets or exceeds the student's expectations." (2001, p. 2). The institutional culture is a critical element in promoting student satisfaction and success (Fullan, 2001). This sentiment is also supported by Kuh, who suggested that "a college's cultural elements can influence student satisfaction, achievement, and ultimately whether a student persists and graduates" (2001-2002, p. 37). The institutional culture, or campus climate, significantly influence the student experience. One study by Schreiner \& Nelson found that "Students' satisfaction with the Campus Climate indicates that they fell a sense of belonging on campus, are proud of the institution they have chosen to attend, enjoy the role of being a student, and feel welcome on their campus." (2013, p. 104). When students feel supported by the campus community, they tend to be more satisfied and ultimately more successful.

\subsection{Latino/a Student Satisfaction}

As this study is focused on Latino/a students, it is important to understand what factors affect student satisfaction for Latino/as. Like all students, satisfaction for Latino/a students is related to items such as faculty-student interaction, learning, and engagement (Hernandez, 2000). Like other diverse student populations, Latino/a students are also concerned about 
campus climate and acculturation issues as well.

There is a significant correlation between learning and satisfaction with faculty-student interaction for Latino/as (Lundberg \& Schreiner, 2004; Umbach \& Wawrzynski, 2005). Looking only at Mexican-American students, positive affect, acculturation, college self-efficacy, college outcome expectations, and academic goals are significant predictors of overall academic satisfaction (Ojeda, Flores, \& Navarro, 2011).

Diversity and campus climate are correlated with higher levels of satisfaction for Latino/a students. For Latino/a students attending traditionally White universities, Park (2009) found that the higher level of heterogeneity on campus correlated with higher levels of student satisfaction. However, there is little difference between levels of satisfaction for Latino/a students attending a primarily Hispanic-serving Institution (HSI) as compared to Latino/a students attending a predominately White institution (Nelson Laird, Bridges, Morelon-Quainoo, \& Williams, 2007). Although not directly related to academic satisfaction, Latino/a students that experience ethnicity challenges such as prejudice, conformity pressures, and stereotype confirmation concerns have lower levels of overall life satisfaction in college (Ojeda, Navarro, Meza, \& Arbona, 2012). This is especially true for younger Latino/a college students.

Higher levels of satisfaction also correlate with high levels of retention and persistence for Latino/a college students. Research on diverse student groups observed a significant relationship between persistence and satisfaction for students of color (Fischer, 2007). Fischer found that "for each one-point increase in satisfaction with college decreased the odds of leaving by $24 \%$ for Blacks $(\beta=-0.268)$ and $33 \%$ for Hispanics $(\beta=-0.398)$ ” (p. 151).

Very little research has been conducted on the satisfaction of Latino/a students with academics and their majors (Nauta, 2007). However, the research conducted by Flores et al. (2014) did find that students' self-efficacy, expectations, and level of interest all directly influenced students' levels of academic satisfaction. This dearth of research on Latino/a student satisfaction in higher education reinforces the importance of research such as this, which can help institutions better understand how to help students' succeed.

\section{Methodology}

\subsection{Participants}

The University of California (UC) system is listed in California's master plan for higher education as the state's premiere institutions (UC Office of the President, 2007). The State established UC institutions to conduct scholarly research and maintain the highest admission's standards. The UC system administers the University of California undergraduate experience survey (UCUES) to all UC students on an annual basis (UC Regents, 2015). The 2010 UCUES resulted in a total of 171,859 responses. A total of $39,307(22.9 \%)$ self-identified as junior or senior-level students. 


\subsection{Measures}

A total of 20 variables, including three dependent variables (i.e., satisfaction with academic advising, satisfaction with course availability, and satisfaction with quality of instruction) and 17 independent variables, were used in this research. Data were cleaned to meet the statistical assumptions of this study and missing data were imputed using EM algorithms. Students' entry characteristics and academic majors were dummy coded for the purpose of data analysis (see Appendix A for details).

A set of factor analysis and reliability statistics were conducted on all student satisfaction variables, with the exception of those variables related to students' academic major experiences (see Appendix B for details). Factors were also confirmed for campus climate for personal characteristics, freedom of personal expression, campus climate for freedom of expression, and student participation in faculty research. Multivariate outliers were identified and removed from the analysis according to their Mahalanobis distance (Tabachnick \& Fidell, 2007). After the data had been reviewed and prepared, two statistical methods were used to analyze student satisfaction.

\section{Results}

The data was analyzed by conducting an analysis of variance (ANOVA) and multiple hierarchical regressions (MHR) on the 2010 UCUES dataset. Due to sample sizes, the ANOVA comparing satisfaction rates only included African-American, Asian, Latino/a, and White students (see Table 1 for details). The ANOVA results were all significant at the .001 level (see Table 2), therefore a Tukey post hoc analysis of the data was conducted to determine intergroup differences. The post hoc analysis determined that Latino/a student satisfaction significantly differed from Asian students in all three areas and from African-American students in satisfaction with the quality of instruction. No significant differences were found between the satisfaction levels of White and Latino/a students.

After confirming significant differences in satisfaction levels existed between Latino/as and other groups, separate MHRs were conducted to determine which variables predict each area of Latino/a students' satisfaction (see Table 4). Each MHR consisted of four blocks: students' entry characteristics, academic major, campus climate, and academic engagement. Students' entry characteristics were represented by student gender, first-generation status, social class, birth location (inside or outside the United States), English first-language speaker, and transfer student status. Students' majors were separated into five categories: humanities, social sciences, STEM, professional, and other. Campus climate consisted of the institutional climate for students' personal characteristics, students' freedom to express their personal beliefs, and the institutional climate for how well students' personal beliefs are respected. Finally, academic engagement was represented by students' engaging in research with faculty, increasing academic effort to meet faculty expectations, extensively editing a paper prior to submission, and time spent engaging in extracurricular activities (as a detractor). All three MHRs found highly significant predictors for satisfaction among Latino/as $(\mathrm{p}<.001)$. 
Block 3, campus climate, had the highest effect size on all three satisfaction areas. Students' perception of how accepting the campus climate was of personal differences was the largest predictor of students' satisfaction in all three areas. Freedom to express personal beliefs had effect sizes similar to when students raised their academic effort level to meet an instructor's expectations. However, the perceived climate for individual's beliefs was not a significant predictor in any area.

Students' academic engagement, block 4, was consistently predictive of students' satisfaction, but with low overall effect sizes. Involvement in research with a faculty member positively predicted satisfaction with course availability and quality of instruction, but not course availability. Increased academic effort to meet faculty expectations had the highest effect in block 4, and significantly predicted satisfaction in all three areas. However, extensively editing a paper predicted satisfaction for course availability and quality of instruction, but not for advisement. Finally, extracurricular engagement had no predictive value on students' satisfaction levels.

Only a few of the students' entry characteristics were consistent or effective predictors of satisfaction levels. First generation students had higher satisfaction levels, but the effect size was consistently very small. Satisfaction with advising was predicted by first-generation status and birth location. Students' satisfaction with course availability was predicted by first-generation status and social class, and inversely related to being a native English speaker. Satisfaction with instruction was predicted by first-generation status and social class. Students' majors, gender, and transfer status were not predictive of any form of student satisfaction.

Table 1. Levels of Satisfaction by Students' Race

\begin{tabular}{|c|c|c|c|c|c|}
\hline & $\begin{array}{c}\text { African } \\
\text { American } \\
(967)\end{array}$ & $\begin{array}{c}\text { Latino/a } \\
(5,573)\end{array}$ & $\begin{array}{c}\text { Asian }^{\mathrm{a}} \\
(15,174)\end{array}$ & $\begin{array}{c}\text { White } \\
(13,105)\end{array}$ & $\begin{array}{c}\text { Total } \\
(34,819)\end{array}$ \\
\hline & $\mathrm{M}(\mathrm{SD})$ & $\mathrm{M}(\mathrm{SD})$ & $\mathrm{M}(\mathrm{SD})$ & $\mathrm{M}(\mathrm{SD})$ & $\mathrm{M}(\mathrm{SD})$ \\
\hline $\begin{array}{l}\text { Satisfaction with Course } \\
\text { Availability }\end{array}$ & $3.91(1.02)$ & $3.95(1.02)$ & $3.87(.97)$ & $3.94(1.03)$ & $3.91(1.00)$ \\
\hline $\begin{array}{l}\text { Satisfaction with } \\
\text { Academic Advising }\end{array}$ & $4.23(.90)$ & $4.28(.89)$ & $4.15(.84)$ & $4.27(.89)$ & $4.22(.87)$ \\
\hline $\begin{array}{l}\text { Satisfaction with Quality } \\
\text { of Instruction }\end{array}$ & $4.47(.76)$ & $4.57(.74)$ & $4.33(.74)$ & $4.55(.76)$ & $4.46(.76)$ \\
\hline
\end{tabular}

a Includes Hawaiian and Pacific Islander students. 
Table 2. ANOVA Results Comparing Students' Satisfaction Levels by Race

\begin{tabular}{|c|c|c|c|c|c|}
\hline & & $\begin{array}{l}\text { Sum of } \\
\text { Squares }\end{array}$ & $\mathrm{df}$ & $\begin{array}{l}\text { Mean } \\
\text { Square } \\
\end{array}$ & $\mathrm{F}$ \\
\hline \multirow[t]{3}{*}{$\begin{array}{l}\text { Satisfaction with Course } \\
\text { Availability }\end{array}$} & $\begin{array}{l}\text { Between } \\
\text { Groups }\end{array}$ & 50.75 & 3 & 16.92 & \multirow[t]{3}{*}{$16.86^{* * *}$} \\
\hline & $\begin{array}{l}\text { Within } \\
\text { Groups }\end{array}$ & 34944.60 & 34815 & 1.00 & \\
\hline & Total & 34995.35 & 34818 & & \\
\hline \multirow[t]{3}{*}{$\begin{array}{l}\text { Satisfaction with Academic } \\
\text { Advising }\end{array}$} & $\begin{array}{l}\text { Between } \\
\text { Groups }\end{array}$ & 115.12 & 3 & 38.38 & \multirow[t]{3}{*}{$50.70 * * *$} \\
\hline & $\begin{array}{l}\text { Within } \\
\text { Groups }\end{array}$ & 26353.57 & 34815 & .76 & \\
\hline & Total & 26468.69 & 34818 & & \\
\hline \multirow[t]{3}{*}{$\begin{array}{l}\text { Satisfaction with Quality of } \\
\text { Instruction }\end{array}$} & $\begin{array}{l}\text { Between } \\
\text { Groups }\end{array}$ & 415.81 & 3 & 138.60 & \multirow[t]{3}{*}{$247.41 * * *$} \\
\hline & $\begin{array}{l}\text { Within } \\
\text { Groups }\end{array}$ & 19503.74 & 34815 & .56 & \\
\hline & Total & 19919.54 & 34818 & & \\
\hline
\end{tabular}

$* * * \mathrm{p}<.001$

Table 3. Post Hoc Comparison of Latino/a Students' Satisfaction with Other Races Mean Difference Between Groups

Std. Error

Satisfaction with Course Availability

African American

.05

.03

Asian

$.09^{* * *}$

.02

White

.01

.02

Satisfaction with Academic Advising

African American

.05

.03

Asian

$.12^{* * *}$

.01

White

.01

.01

Satisfaction with Quality of Instruction

African American

Asian

White

$* * * \mathrm{p}<.001, * * \mathrm{p}<.01, * \mathrm{p}<.05$.

\section{Discussion and Implications}




\section{1 Differences in Levels of Satisfaction}

The first research questions for this study were: What are the levels of academic satisfaction among Latino college students at highly selective institutions? How are the levels different from those of their peers of other racial groups? This study used three methods of measuring academic satisfaction: (1) Satisfaction with Course Availability, (2) Satisfaction with Academic Advising, and (3) Satisfaction with Quality of Instruction. The ANOVA results showed there are significant differences in academic satisfaction between the ethnic groups. In general, Latino/a students surveyed tend to be more satisfied in all three domains measured. Previous research (Hurtado \& Carter, 1997; Hurtado et al., 2002; Hurtado \& Ponjuan, 2005; Juillerat \& Schreiner, 2004) has identified significant differences between the ethnic groups. Inconsistent with previous research is the fact that Latino/a students in this study have higher levels of academic satisfaction, as compared to their peers in other race groups.

Of particular interest in this study are the differences between the ethnicities in each of the three academic satisfaction domains. The results of this study show that Latino/as are significantly more satisfied with course availability and academic advising than Asians. However, there is no significant difference in these areas from White and African-American students. For satisfaction with quality of instruction, Latino/as are significantly more satisfied than Asian students and African-American students. Again, there is no significant difference in the level of satisfaction with quality of instruction between Latino/a students and their White peers.

Other research has identified significant differences in levels of satisfaction between White students and Latino/a students (Milem, 2003). However, most of the previous research has also shown that White students are more satisfied, especially when attending a predominately White-serving institution (Park, 2009). It is interesting to note, therefore, that the Latino/a students in this study reported slightly higher levels of satisfaction in all three areas when compared with their peers.

The differences noted in this study suggest that colleges and universities may need to tailor programs and support that fits both White and Latino/a students, as well as programs that are designed to fit the needs of African American and Asian students. As an alternate view, the results also suggest that programs developed to support Latino/as will also support White students. This finding may be beneficial for predominately Hispanic-serving institutions as the programs and support services that exist at these institutions may be just as beneficial for White as their Latino/a counterparts.

Table 4. Multiple Hierarchical Regression Analysis Predicting Student Satisfaction with 
Advising, Course Availability, and Quality of Instruction from Campus Climate and Student Engagement

\begin{tabular}{|c|c|c|c|c|c|c|}
\hline \multirow[b]{2}{*}{ Predictor } & \multicolumn{2}{|c|}{$\begin{array}{l}\text { Satisfaction with } \\
\text { Advising }\end{array}$} & \multicolumn{2}{|c|}{$\begin{array}{c}\text { Satisfaction with Course } \\
\text { Availability }\end{array}$} & \multicolumn{2}{|c|}{$\begin{array}{l}\text { Satisfaction with Quality } \\
\text { of Instruction }\end{array}$} \\
\hline & $\Delta R^{2}$ & $\beta$ & $\Delta R^{2}$ & $\beta$ & $\Delta R^{2}$ & $\beta$ \\
\hline Step 1 & $.01 * *$ & & $.01 * * *$ & & $.01 * * *$ & \\
\hline Gender & & -.04 & & -.03 & & -.03 \\
\hline First-Generation & & $.05^{*}$ & & $.07 * * *$ & & $.04 *$ \\
\hline Social Class & & .02 & & $.06^{* *}$ & & $.05 *$ \\
\hline Born in U.S. & & $.05^{*}$ & & .03 & & .03 \\
\hline Native English speaker & & -.02 & & $-.04 *$ & & -.04 \\
\hline Transfer student & & -.03 & & -.01 & & -.03 \\
\hline Step 2 & $.01 * * *$ & & $.01 * * *$ & & $.02 * * *$ & \\
\hline Humanities Major & & .12 & & .09 & & .11 \\
\hline Social Sciences Major & & .07 & & -.00 & & .09 \\
\hline STEM Major & & .00 & & -.01 & & -.03 \\
\hline Professional Studies Major & & .04 & & .04 & & .06 \\
\hline Other Major & & .08 & & .06 & & .11 \\
\hline Step 3 & $.07 * * *$ & & $.07 * * *$ & & $.08 * * *$ & \\
\hline Climate for personal characteristics & & $.17 * * *$ & & $.18 * * *$ & & $.20 * * *$ \\
\hline Freedom to express personal beliefs & & $.09 * * *$ & & .04 & & $.09 * * *$ \\
\hline $\begin{array}{l}\text { Climate for respect of personal } \\
\text { beliefs }\end{array}$ & & .03 & & .06 & & .02 \\
\hline Step 4 & $.02 * * *$ & & $.01 * * *$ & & $.03 * * *$ & \\
\hline Research with faculty & & .04 & & $.05 * *$ & & $.04 *$ \\
\hline $\begin{array}{l}\text { Raised academic effort level to meet } \\
\text { faculty expectations }\end{array}$ & & $.11^{* * *}$ & & $.07 * * *$ & & $.14 * * *$ \\
\hline $\begin{array}{l}\text { Extensively edited a paper prior to } \\
\text { submission }\end{array}$ & & $.05^{* *}$ & & .00 & & $.05^{* *}$ \\
\hline Extracurricular engagement & & .03 & & .02 & & -.01 \\
\hline Total $R^{2}$ & $.10 * * *$ & & $.09^{* * *}$ & & $.13 * * *$ & \\
\hline
\end{tabular}

$* * * \mathrm{p}<.001, * * \mathrm{p}<.01, * \mathrm{p}<.05$

\subsection{Predictors of Academic Satisfaction for Latino Students}

The second set of research questions in this study were: (1) What college experiences contribute to the levels of academic satisfaction among Latino college students at these institutions, and (2) How are the contributing college experiences different from those of their counterparts of other racial groups?

For the predictors of academic satisfaction, two themes emerge. First, the campus climate is important to Latino students. Second, academic effort and challenge leads to higher levels of academic satisfaction for Latino students. Each of these themes will be explored in more 
depth.

Campus climate continues to be a significant predictor of satisfaction for Latino students. Previous studies have identified the significant correlation between satisfaction measures and campus climate for Latino/a students (Ojeda, Edwards, Hardin, \& Piña-Watson, 2014; Park, 2006). This study shows that campus climate specifically affects academic satisfaction for Latino/a students. In fact, the largest change in $\mathrm{R}^{2}$ was noted in Block 3 , in which campus climate was measured. For the three measurements of student satisfaction at Block 3, the models were able to explain between 7 percent and 8 percent of the total variation in academic satisfaction. This finding supports past research and adds to the literature by applying a specific lens to evaluate academic satisfaction, which is a sub-set of overall student satisfaction.

Block 4 of the regression models showed that both engagement with faculty and elevated academic effort are significant predictors of academic satisfaction for Latino/a students. The opportunity to work with faculty has been shown to be an important predictor of satisfaction in previous research (Lundberg \& Schreiner, 2004).

Several implications can be derived from these results. First, the campus climate matters for Latino/a students. Park (2009) found, and this research confirms, that a campus climate that promotes heterogeneity and diversity supports the overall satisfaction of Latino/a students. This research examined one aspect of satisfaction, academic satisfaction, and found that campus climate had the strongest effect on Latino/a student satisfaction. Therefore, college and university administrators should work to develop a climate of inclusion and respect.

Second, Latino/a students thrive with academic challenge. For all of the measures of academic satisfaction, when Latino/a students raised their level of effort to meet faculty expectation, they were more satisfied. This means that faculty should continue to hold high expectations for all students and ask those students to meet the challenge. Previous research has identified that students are more engaged when they feel challenged (Umbach \& Wawrzynski, 2005). For Latino/a students, the higher level of challenge creates higher levels of academic satisfaction, which ultimately leads to other outcomes such as engagement and persistence to degree completion.

When considering the relationship between academic challenge and satisfaction, the classroom experience must be rewarding as well. In this study, the models were able to predict $13 \%$ of the variation in Latino/a students' satisfaction with quality of instruction. Knowing that quality of instruction matters to Latino/a students, faculty should develop curriculum and teaching methods that stimulate and challenge the learner. Latino/a students will benefit from a challenging classroom experience. Not only will levels of Latino/a student satisfaction be higher, but research has also show a direct correlation between the stimulating classroom and student learning (Lundberg \& Schreiner, 2004).

Finally, faculty-student interaction is important for Latino students. Other researchers (Kuh et al., 2006; Lundberg \& Schreiner, 2004; Umbach \& Wawrzynski, 2005) have shown that positive faculty-student interactions result in many positive student outcomes, including 
student satisfaction. When considering academic satisfaction, this study supports the previous research. Therefore, it is important for faculty and administrators to create opportunities for Latino students to work with faculty outside of the classroom as well. Undergraduate research programs will support the academic satisfaction of Latino students.

\section{Limitations}

As with every piece of research there are limitations that must be recognized. First, the dataset for this project was limited to results from one, large university system on the West Coast. Additionally, the university system is comprised of mainly R1-type institutions. As such, the results may differ when other institution types are considered. Second, this study looked at the results for only Junior and Senior Latino students. Again, results may differ when freshmen, sophomores, and even graduate students are examined. Finally, regression analyses do not show causation, they only reveal the correlations between the variables. In this study, even though the results of the hierarchical regressions are significant, it does not necessarily mean that Latino students are highly satisfied because of the independent variables in the models.

\section{Areas for Future Research}

As this study was focused on Junior and Senior Latino/a students attending a large, public university system, there is opportunity for additional research to confirm these results. Students at other institution types should be surveyed. The results may be different at small, private schools because the institutions in this study were all public research universities.

This study focused on Latino/a students who were upperclassmen (i.e., juniors and seniors). To further understand academic satisfaction for Latino/a students, other student types should be examined. The experiences and satisfaction of freshmen, sophomores, and graduate students may be different and may provide additional insight to the research questions posed in this study.

Similar research should also be conducted at Hispanic-serving institutions (HSIs). This study looked at one public university system that has a relatively diverse student population. HSIs have the systems, procedures, programs, policies, and mindset to specifically cater to the Latino/a student. Therefore, it is important to recreate this study using data collected at HSIs to understand if the predictors of academic satisfaction are different on those campuses.

\section{Conclusion}

To better serve diverse student populations, it is necessary to understand what factors lead to student success in college. This study adds to the existing literature on student satisfaction as well as the literature on diverse student populations. Finally, this paper offers implications for practice and suggestions for colleges and universities that serve Latino/a students as well as other student populations.

\section{References}


Aitken, N. D. (1982). College student performance, satisfaction and retention: Specification and estimation of a structural model. Journal of Higher Education, 53(1), 32-50. http://dx.doi.org/10.2307/1981537

Astin, A. W. (1993). What matters in college?: Four critical years revisited (1st ed.). San Francisco: Jossey-Bass.

Bailey, T. (2009). Challenge and opportunity: Rethinking the role and function of developmental education in community college. New Directions for Community Colleges, 145, 11-30. doi: 10.1002/cc.352

Bean, J. P., \& Bradley, R. K. (1986). Untangling the satisfaction-performance relationship for college students. Journal of Higher Education, 57(4), 393-412. http://dx.doi.org/10.2307/1980994

Beltyukova, S. A., \& Fox, C. M. (2002). Student satisfaction as a measure of student development: Towards a universal metric. Journal of College Student Development, 43, 161-172.

Borden, J. L. (1995). Segmenting student markets with a student satisfaction and priorities survey. Research in Higher Education, 36(1), 73 - 88. http://dx.doi.org/10.1007/BF02207767

Bryant, J. L. (2006). Assessing expectations and perceptions of the campus experience: The Noel-Levitz Student Satisfaction Inventory. New Directions for Community Colleges, 134, 25-35. doi: $10.1002 / \mathrm{cc} .234$

DeShields Jr., O. W., Kara, A., \& Kaynak, E. (2005). Determinants of business student satisfaction and retention in higher education: Applying Herzberg's two-factor theory. International Journal of Educational Management, 19(2), 128-139. doi: $10.1108 / 09513540510582426$

Dolinsky, A. L. (2010). The adequacy of the information that students utilize when choosing a college: An attribute importance and information sufficiency approach. College Student Journal, 44(3), 762-776.

Elkins, S. A., Braxton, J. M., \& James, G. W. (2000). Tinto's separation stage and its influence on first-semester college student persistence. Research in Higher Education, 41(2), 251-268. doi: 10.1023/A:1007099306216

Elliot, K. M., \& Healy, M. A. (2001). Key factors influencing student satisfaction related to recruitment and retention. Journal of Marketing for Higher Education, 10(4), 1-11. http://dx.doi.org/10.1300/J050v10n04_01

Fischer, M. J. (2007). Settling into campus life: Differences by race/ethnicity in college involvement and outcomes. Journal of Higher Education, 78(2), 125-161. doi: 10.1353/jhe.2007.0009

Flores, L. Y., Navarro, R. L., Lee, H. S., Addae, D. A., Gonzalez, R., Luna, L. L., Mitchell, M. (2014). Academic satisfaction among Latino/a and White men and women engineering 
students. Journal of Counseling Psychology, 61(1), 81-92. doi: 10.1037/a0034577

Fullan, M. (2001). Leading in a Culture of Change. San Francisco, CA: Jossey-Bass.

Hernandez, J. C. (2000). Understanding the retention of Latino college students. Journal of College Student Development, 41(6), 575-588.

Hoyt, J. E., \& Brown, A. B. (2003). Indentifying College Choice Factors to Successfully Market Your Institution. College and University, 78(4), 3-10.

Hurtado, S., \& Carter, D. F. (1997). Effects of college transition and perceptions of the campus racial climate on Latino college students' sense of belonging. Sociology of Education, 324-345. http://dx.doi.org/10.2307/2673270

Hurtado, S., \& Ponjuan, L. (2005). Latino educational outcomes and the campus climate. Journal of Hispanic Higher Education, 4(3), 235-251. doi: 10.1177/1538192705276548

Hurtado, S., Milem, J. F., Clayton-Pedersn, A. R., \& Allen, W. R. (2002). Enhancing campus climates for racial/ethnic diveristy: Education policy and practice. Racial and ethnic diversity in higher education, 671 - 685.

Juillerat, S. L. (1995). Investigating a two-dimensional approach to the assessment of student satisfaction: Validation fo the Student Satisfaction Inventory. (Doctoral Dissertation). Available from Proquest Dissertations \& Theses (UMI No. 304234856)

Juillerat, S. L., \& Schreiner, L. A. (2004). The role of student satisfaction in the assessment of institutional effectiveness. In T. Banta (Ed.), Hallmarks of effective outcomes assessment (pp. 50-55). San Fransico: Jossey-Bass.

Kotler, P., \& Fox, K. F. A. (1995). Strategic Marketing for Educational Insitutions. Englewood Cliffs, NJ: Prentice-Hall.

Kuh, G. D. (2001-2002). Organizational Culture and Student Persistence: Prospects and Puzzles. Journal of College Student Retention: Research, Theory, \& Practice, 3(1), 23-29. http://dx.doi.org/10.2190/U1RN-C0UU-WXRV-0E3M

Kuh, G. D., Kinzie, J., Buckley, J. A., Bridges, B. K., \& Hayek, J. C. (2006). What matters to student success: A review of the literature. Bloomington, IN: National Postsecondary Education Cooperative.

Kuh, G. D., Kinzie, J., Schuh, J. H., Whitt, E. J., \& Associates. (2005). Student success in college: Creating conditions that matter. San Francisco: Jossey-Bass.

Lopez, M. H., \& Fry, R. (2013). Among recent high grads, Hispanic college enrollment rate surpases that of Whites. Fact tank: News in the numbers. http://www.pewresearch.org/fact-tank/2013/09/04/hispanic-college-enrollment-rate-surpasses -whites-for-the-first-time/

Lundberg, C. A., \& Schreiner, L. A. (2004). Quality and frequency of faclty-student interaction as predictors of learning: An analysis by student race/ethnicity. Journal of College 
Student Development, 45(5), 549-565. http://dx.doi.org/10.1353/csd.2004.0061

Meredith, M. (2004). Why do universities compete in the ratings game? An empirical analysis of the effects of the U.S. News and World Report college rankings. Research in Higher Education, 45(5), 443-461. doi: 10.1023/B:RIHE.0000032324.46716.f4

Milem, J. F. (2003). The educational benefits of diversity: Evidence from multiple sectors. In M. Chang, D. Witt, J. Jones, \& K. Hakuta (Eds.), Compelling interest: Examining the evidence on racial dynamics in higher education (pp. 126-169). Stanford, CA: Standford Education.

Nauta, M. M. (2007). Assessing college students' satisfaction with their academic majors. Journal of Career Assessment, 15(4), 446-462. doi: 10.1177/1069072707305762

Nelson Laird, T. F., Bridges, B. K., Morelon-Quainoo, C. L., \& Williams, J. M. (2007). African American and Hispanic student engagement at minority serving and predominately White institutions. Journal of College Student Development, 48(1), 39-56. http://dx.doi.org/10.1353/csd.2007.0005

Noel-Levitz. (2014). National Student Satisfaction and Priorities Report. Coralville, IA.

Nora, A. (2004). The role of habitus and cultural capital in choosing a college, transitioning from high school to higher education, and persisting in college among minority and nonminority students. Journal of Hispanic Higher Education, 3(2), 180-208. http://dx.doi.org/10.1177/1538192704263189

Nora, A., \& Cabrera, A. F. (1996). The role of perceptions of prejudice and discrimination on the adjustment of minority students to college. The Journal of Higher Education, 119-148. http://dx.doi.org/10.2307/2943977

Ojeda, L., Edwards, L. M., Hardin, E. E., \& Piña-Watson, B. (2014). The role of behavioral and cognitive cultural orientation on Mexican American college students' life satisfaction. Journal of Hispanic Higher Education, 13(1), 63-74. doi: 10.1177/1538192713513464

Ojeda, L., Flores, L., \& Navarro, R. L. (2011). Social cognitive predictors of Mexican American college students' academic and life satisfaction. Journal of Counseling Development, 58(1), 61. http://dx.doi.org/10.1037/a0021687

Ojeda, L., Navarro, R. L., Meza, R. R., \& Arbona, C. (2012). Too Latino and not Latino enough: The role of ethnicity-related stressors on Latino college students' life satisfaction. Journal of Hispanic Higher Education, 11(1), 14-28. doi: 10.1177/1538192711435553

Park, J. J. (2006). A look at satisfaction with ethnic diversity of the student body for White, Black, Latino/a, and Asian American students. Paper presented at the Assocation for the Study of Higher Education Annual Conference, Madison, WI.

Park, J. J. (2009). Are We Sastisfied?: A Look at Student Satisfaction with Diversity at Traditionally White Institutions. The Review of Higher Education, 32(3), 291-320. http://dx.doi.org/10.1353/rhe.0.0071 
Pascarella, E. T., \& Terenzini, P. T. (2005). How college affects students: A third decade of research. San Francisco: Jossey-Bass.

Pate, W. S. (1993). Consumer satisfaction, determinants, and post-purchase actions in higher education. College and University, 68(2), 100-107.

Pike, G. R. (1993). The relationship between perceived learning and satisfaction with college: An alternate view. Research in Higher Education, 34(1), 23-40. doi: 10.1007/BF00991861

Scanlon, E., \& McComis, M. S. (2010). Accreditation and accountability: The role of for-profit education and national accrediting agencies. In G. C. Henschke, V. M. Lechuga, \& W. G.

Schreiner, L. A., \& Louis, M. (2006). Measuring engaged learning in college students: Beyond the borders of the NSSE. Paper presented at the Association for the Study of Higher Education, Anaheim, CA.

Schreiner, L. A., \& Louis, M. (2008). The Engaged Learning Index: Implications for faculty development. Paper presented at the annual meeting of the Association for the Study of Higher Education, Jacksonville, FL.

Schreiner, L. A., \& Nelson, D. D. (2013). The contribtion of student satisfaction to persistence. Journal of College Student Retention, 15(1), 73.111. http://dx.doi.org/10.2190/CS.15.1.f

Suhre, C. J. M., Jansen, E. P. W. A., \& Harskamp, E. G. (2007). Impact of degree program satisfaction on the persistence of college students. Higher Education, 54(2), 207-226. doi: $10.1007 / \mathrm{s} 10734-005-2376-5$

Tabachnick, B. G., \& Fidell, L. S. (2007). Using Multivariate Statistics (5th ed.). Boston: Allyn and Bacon.

Tierney (Eds.), For-profit colleges and universities: Their markets, regulation, performance, and place in higher education (pp. 109-144). Sterling, VA: Stylus.

Tinto, V. (1993). Leaving college: Rethinking the cause and cures of student attrition (2nd ed.). Chicago: University of Chicago Press.

UC Office of the President. (2007). Major features of the California master plan for higher education. Retrieved from http://www.ucop.edu/acadinit/mastplan/mpsummary.htm

UC Regents. (2015). Methodology. Retrieved from http://studentsurvey.universityofcalifornia.edu/about/method.html

Umbach, P. D., \& Wawrzynski, M. R. (2005). Faculty do matter: The role of college faculty in student learning and engagement. Research in Higher Education, 46(2), 153-184. doi: $10.1007 / \mathrm{s} 11162-004-1598-1$

United States Census Bureau. (2014). Data Access Tools. Retrieved August 27, 2014, from http://www.census.gov/main/www/access.html 
Williams, J. (2002). Student satisfaction: A British model of effective use of student feedback in quality assurance and enhancement. Paper presented at the 14th International Conference on Assessment and Quality in Higher Education, Vienna

Appendix A. Factor Loadings and Internal Reliability on Factor Scales

\begin{tabular}{lr}
\hline \multicolumn{1}{c}{ Factors and Survey Items } & Factor Loar \\
\hline Satisfaction with academic advising & .85 \\
Satisfaction: advising by college staff on academics & .82 \\
Satisfaction: advising by departmental staff on & .71 \\
academic matters & .70 \\
Satisfaction: advising by faculty on academic matters & \\
Satisfaction: advising by peer advisors on academics &
\end{tabular}

Satisfaction with course availability

Satisfaction: availability of general education course

Satisfaction: availability of courses needed for

graduation

Satisfaction: access to small classes

Satisfaction: quality of lower-division courses in your major

Satisfaction: quality of upper-division courses in your major

Satisfaction: quality of faculty instruction

Satisfaction: quality of teaching by TAs

Involved in research with a faculty member

Faculty research for pay

Faculty research for course credit 
Time allocation: Attend movies, concerts, sports or other events

Time allocation: pursuing a recreational/creative interest

Time allocation: socializing with friends

Time allocation: partying

Time allocation: watching tv

Subfactor 6a: Climate for Personal Characteristics

Students are respected here regardless of their economic or social class

Students are respected here regardless of their gender

Students are respected here regardless of their race or ethnicity

Students are respected here regardless of their sexual orientation

Subfactor 6b: Freedom to Express Beliefs

I feel free to express my political beliefs on campus

I feel free to express my religious beliefs on campus

Subfactor 6c: Climate of Respect for Personal Beliefs

Students are respected here regardless of their religious

beliefs

Students are respected here regardless of their political beliefs

\section{Copyright Disclaimer}

Copyright reserved by the author(s).

This article is an open-access article distributed under the terms and conditions of the Creative Commons Attribution license (http://creativecommons.org/licenses/by/3.0/). 